\title{
Settlement-Territorial Identity
}

\author{
Zoltán Birkner, PhD \\ University of Pannonia, Hungary \\ Tivadar Máhr \\ University of Pannonia, Hungary \\ Nora Rodek, PhD \\ University of Pannonia, Hungary
}

\section{Abstract}

Belonging to groups is an integral part of our lives. We can interpret this to our narrower environment (family, friends, workplace), or in the extended space, to our cities and regions. These bonds only exist as long as the members consider the relationship valuable and important. Binding to a group is called identity. A research was carried out in 2017 in which we interviewed the decision makers of Central European cities about territorial identity. In this study we intend to interpret identity primarily on a territorial basis. Furthermore, we examine the elements of settlement identity, find good practices according to settlement affiliation and present the research results.

Keywords: territorial identity, good practices, community development JEL classification: $\mathrm{O35}$

\section{Introduction}

The authors are convinced that small- and medium sized cities in the Europe of the $21^{\text {st }}$ century have to face many dangers. These dangers are mainly the consequences of globalisation, as these settlements always have to compete with the bigger and stronger ones for investments, tourists and for keeping the young and middle-aged population in place. This competition cannot be avoided as information is - owing to the internet - available in almost every household and on mobile phones. Liveability and calmness, as advantages, are almost exclusively important for the elderly (and some services), thus companies, institutions and the youth settle in places where many things are available, where there are broad markets, many possibilities and there is a wide-range of available employees as well. The following questions were raised: what can small- and medium-sized cities do to reduce emigration and what is necessary to be able to attract those youth back who left for learning? Unveiling the literature of identity can help to answer these questions. The authors strive to find the organisational-operational model for mayors of cities and decision-makers which can help to interpret the practical things that need to be done. The authors hypothesise the existence of a theoretical model that supports the development of urban identity which, if understood and used can bring success to the leaders of small- and medium-sized cities in strengthening the identity.

\section{Concepts of identity}

The definition of the term of identity requires Jenkins (2008), according to whom the term refers to the whole universe of creatures and this includes two comparison criteria: the difference and similarity between people and things. Identity is suitable for identifying and classifying individuals and groups, however it is never a final affair. 
The research of the term is a favoured topic of sociologists, everybody has an opinion and an approach, therefore psychologists, sociologists, geographers, political scientists, regional development and marketing experts have often written various works about this topic in the past decades.

Pataki (1986, p. 9) considers identity to be the sense of being the same and the gist is the individual takes in the community. There are many identities, occupational, sexual, family-related etc., the type of connection is always defined by the relation of the individual and the community.

Identity is developed by interacting with others and can be deduced from the pattern of familiarising with ourselves and becoming recognised. Thus personal identity always has a social dimension. Similar values and understanding are needed in the search for collective identity. The characteristic feature of this concept is not "familiarising with myself", but the highlighting of being different from other people (Palkó, 2011, p. 14-15).

Table 1

Types of Identity

\begin{tabular}{ccc}
\hline Object & Perspective & $\begin{array}{c}\text { self-definition } \\
\text { (me-picture) }\end{array}$ \\
\hline individual & $\begin{array}{c}\text { external picture } \\
\text { (me-sense) }\end{array}$ & social identity \\
group & $\begin{array}{c}\text { group identity } \\
\text { (us-sense) }\end{array}$ & $\begin{array}{c}\text { group identity } \\
\text { (being outside the group) }\end{array}$ \\
\hline
\end{tabular}

Source: Palkó, 2011, p. 15 based on Werthmöller 1995

The above table shows that identity concepts focus on the individual, on communities and groups. Social identity and the self-definition of group identity are of importance from the point of view of the present research, as regionality can be interpreted in the best way in this context. The urban development aspect of identity is in the focus within sociology with the term being understood as a major tool of settlement marketing.

\section{The regional identity}

A slow change from two perspectives took place in the perspective of selfgovernments (mainly of cities) first in the United States and then gradually in WestEurope in the last decades of the $20^{\text {th }}$ century. On one hand more attention was paid to the environment and the processes therein and it had to be realised that a more initiative role must be paid in shaping the fate of the areas they were given to take care of (Kozma, 2006, p. 7; Németh, 2017, p. 75). Furthermore, they should not isolate themselves: cooperation between settlements helps them to find solutions to common challenges and problems (Ernszt et al., 2017, p. 144).

Castells explains the foundations of this new perspective according to which the life of mankind is shaped by the conflict processes of globalisation and individualism. The technological revolution, the network society and the virtual culture brought along the rise of a new kind of a cosmopolitan elite while various forms of collective identity emerged to counterbalance this and the regional identity is one of them (Castells, 1997, p. 157). Regional identity is the most decisive on the basis of the measurements taken by Norris (1995-1997-es), with half of the interviewees feeling this 
as the most important grip in an expanding world and the consequence is the strengthening of local values and decision-making (Castells, 2010, p. 336).

Regional/areal identity can be interpreted as the integral part of social sense of identity on the basis of which individuals feel and claim to be parts of a social group which is broader than the personal network and which can defined by geographical categories. The image of the country is closely connected to the identity of its habitants (Malota 2004, 2005), and the self-identity, self-image has an effect on how we evaluate destinations (Gyulavári et al., 2014). The legitimateness of local, regional, legal and political structures largely depend on the identity of the local society and local connection is the basis of a new development source and force (Palkó, 201 1, p. 24).

\section{The $\mathrm{Cl}$ - City Identity}

Developers of the "urban future" will have to cope with huge challenges in the near future (Zsarnoczky, 2016, p. 107). Cities must be developed consciously and this can always be built upon existing resources and competences. The actual development is defined by the decisions of the local population, tourists, enterprises and target groups. These decisions are made on the basis of the competitiveness of the settlement, its attractiveness and the perception thereof and the image. Thus the image, the brand is in the centre of modern development strategies of competing cities (Piskóti, 2012, p. 55). The image is the reputation established by the world outside which does not only contain facts, but also imaginations about the product, and in this case about a city (Anholt, 2010, id. Nagy, 2015, p. 101; Gyulavári, 2017, p. 60; Péter et al., 2014, p. 552; Péter, 2015, p. 158).

The shaping of the city image defines the goals, tools and practical steps of city marketing. The novel, broader interpretation of city marketing and the description of the process received scientific substantiation following the work of Philip Kotler and his colleagues (Kotler et al, 1993). The authors pay special attention to the stages of product development in their work and stipulate that marketing activities can only be successful if the result is a product which is attractive from many perspectives. This product has an individual identity and this identity can be communicated and strengthened for the sake of increasing the local attractiveness (Rainisto, 2003; Kavaratzis, 2004; Michalkó, 2014).

The elements of settlement identity must be learned for the sake of the process of image building. Piskóti (2012) created the notion of City Identity using previous elements and created well-interpretable contents and elements for cities.

The initial element of the conceptual model is the mission (city mission - chart 2), and the future perspectives built upon it (as the desired future condition), and the clear formulation of vocational efforts which must work as a contextual, conceptual place of clearing when the partial activities of the given professional fields are defined. The direction and frame of specific professional efforts must be provided by the decisions of the urban development and the results of marketing planning play a crucial role in the establishment hereof.

Various functional part-strategies are compiled on the basis of city-strategy decisions and the range of activities and performances of specific offerdevelopment is established on the same basis. The author consciously separated these on the chart into two parts: into the sides of vocational performances and communication; these two are obviously not independent, but must work in a way that they build upon each other and take each other into consideration. 
Cl-building is not only a mere communication task, but the affair of the entire city, where marketing and the dominant integrated communication visualise it and measure it and initiate necessary changes (Piskóti, 2012, p. 304-306).

\section{Figure 1}

The A City Identity Concept

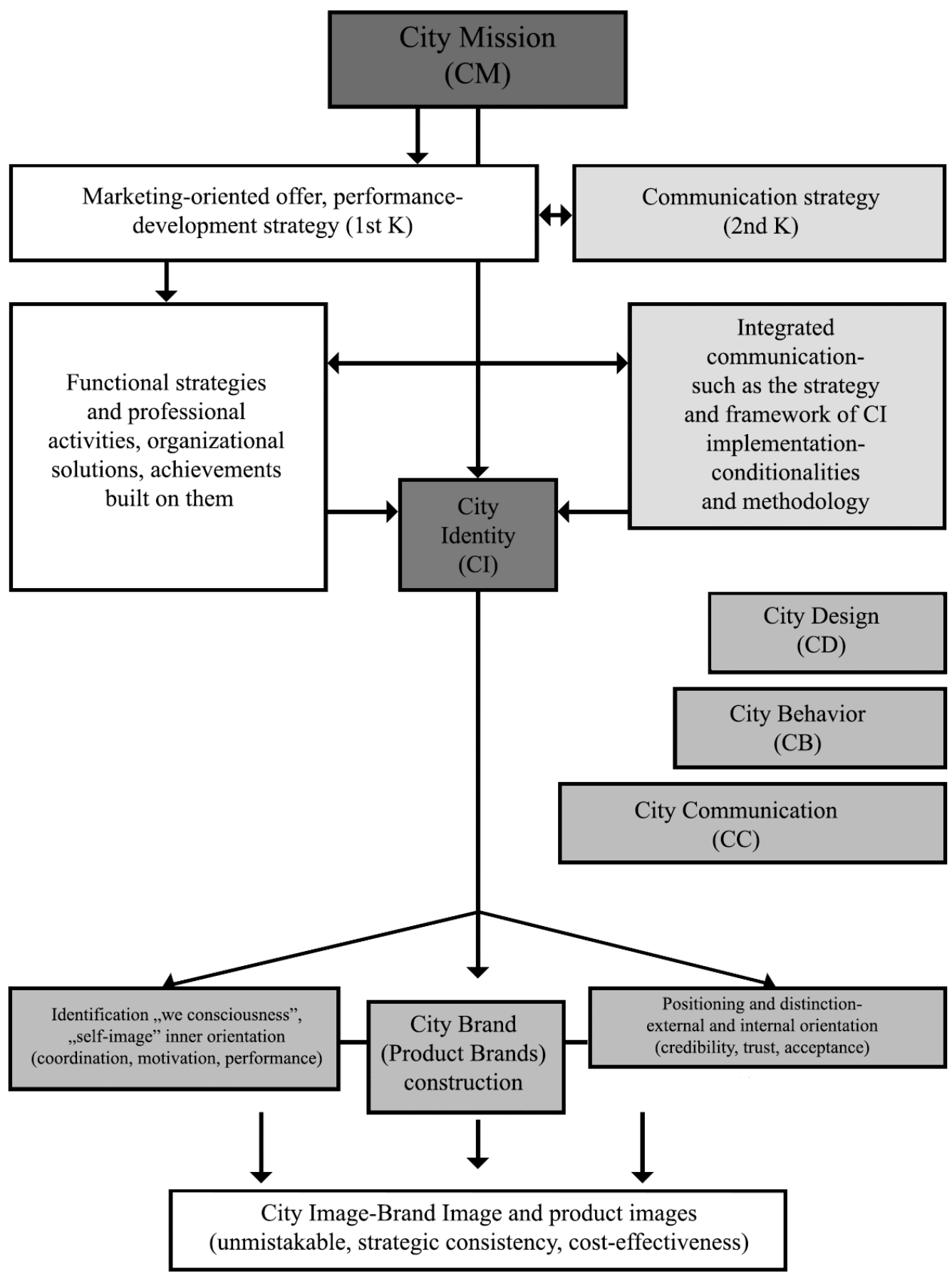

Source: Piskóti, 2012, p. 66 
Before further elements of the image are analysed, the first and second "K" expression in the brackers need to be explained. These Ks mean a new approach, Piskóti summarises the $4 \mathrm{P}$ of the traditional marketing mix (product, price, place, promotion), in order for it to be applied as a tool for settlement marketing. The first among the $2 \mathrm{Ks}$ is the offer mix (the specific product, offer of the settlement can be established based on the characteristics), the second is the communication mix (two-way information stream and selling function) (Piskóti, 2012, p. 56). Two-way communication that characterizes $2 \mathrm{~K}$ can be enforced by different platforms and tools like social media elements that are able to help city identity in a positive way (Markos-Kujbus et al., 2012).

There classical elements must be merged in the communication approach of the $\mathrm{Cl}$ - at least as a start:

- $\quad$ a $C B=$ as the behaviour of all those representing and incarnating the city;

- $\quad$ a $C D=$ as the visual, formal image presentation;

- a $\mathrm{CC}=$ as an activity applying conscious and complex marketing, communication tools, which must promote the unified image by creating the balance among aims, messages and tools, in a process.

The two-fold (internal and external) function of the $\mathrm{Cl}$ is mutually-assuming, but both have a different impact. The internal evaluation and the identity and local patriotism building upon it is helped by the external, positioning and differentiating identity. The brand has a major role in building the internal, but especially the external identity. As a city brand it merges with the Cl-building, while they have a strengthening and constructing function when city-related product brands and organisational brands appear (Piskóti, 2012, p. 305).

"Image is the imprint, the reflection of the brand. The $\mathrm{Cl}$ concept and the activity built upon it are the conscious brand shaping, the acting, while the image is the result thereof. However, it is also known that image is not shaped via the Cl-building only, but it is also formed by always different internal and external intended and unintended factors and they give the conceptual development and practical implementation of $\mathrm{Cl}$ a special importance (Piskóti, 2012, p. 305).

\section{Summary}

If there are many common notions between the self-image, self-picture and external image, structure and culture of a city, then a strong identity can be identified. This is the real aim (Piskóti, 2012. p. 306). An integrated marketing communication is needed however, if settlement communication contribution to image building wants to be achieved. The gist of integrated marketing communication is that it links all information and messages coming from the organisation, in this case from the selfgovernment, and thus it provides the organisation with a kind of an image. Thus commercials and printed advertisements convey the same message, their look and protagonists are similar, just like during electronic and personal communication (TóthKaszás, 2017, p. 240). The above explained City Identity concept clearly shows that building a city identity is a very complex task. It is the matter of the entire city, especially for those representing it on a strategic level. There is no real success without real contents and the bolstering of an identity cannot be achieved with communication only. The joint efforts of a professional and conscious management and excellent marketing and city development experts can bring success, if the inhabitants also know and accept common goals.

The authors believe to have been able to justify the hypothesis, as there is a theoretical model which supports the development of the city image, i.e. Piskóti's City Identity model, which can be interpreted for small- and medium-sized towns 
and the application of which can bring results in strengthening the local identity and thus it can decrease/stop the reduction of the number of inhabitants in a given city.

\section{References}

1. Castells, M. (1997), The Power of Identity, Blackwell Publishers Inc., Cambridge, MA, USA.

2. Castells, M. (2010), The Power of Identity, Second edition, with a new preface, WileyBlackwell.

3. Ernszł, I., Keller, K., Tóth-Kaszás, N. (2017), A települési együttmüködések elmélete és gyakorlata: A Pannon Városok Szövetségének példája (Theory and Practice of Settlement Cooperation: the Association of Pannon Towns), Institute of Higher Education (In Hungarian: Felsőbbfokú Tanulmányok Intézete), Kőszeg.

4. Gyulavári, T. (2017), A projektmarketing tervezése és menedzselése (Designing and managing project marketing), Corvinus University, Budapest.

5. Gyulavári, T., Malota, E. (2014), "Az énkép illeszkedés szerepe a fogyasztók turisztikai desztinációértékelésében" (The role of self-image in the assessment of tourist destination by the consumers), Marketing and Management, Vol. 48, No. 3, pp. 5-14.

6. Jenkins, R. (2008), Social Identity, Third Edition, Routledge, Abingdon, Oxford.

7. Kavaratzis, M. (2004), "From city marketing to city branding: Towards a theoretical framework for developing city brands", Place Branding, Vol. 1, No. 1, pp. 58-73.

8. Kotler, P., Haider, D. H., Rein, I. (1993), Marketing places: attracting investment, industry, and tourism to cities, states, and nations, The Free Press, New York, NY, USA.

9. Kozma, G. (2006), Terület- és településmarketing geográfus és földrajz tanár szakos hallgatók számára (Territory and settlement marketing for geography teachers), Kossuth Publishing, Debrecen.

10. Malota, E. (2004), "Az országeredet imázs I" (Countryside image I), Marketing \& Management, Vol. 38, No. 4, pp. 49-60.

11. Malota, E. (2005), "Az országeredet imázs II" (Countryside image II), Marketing \& Management, Vol. 39, No. 1, pp. 122-130.

12. Markos-Kujbus É., Gáti M. (2012), A közösségi média, mint online stratégiai eszköz (Social Media as an Online Strategic Tool), the 18th National Conference of the Hungarian Marketing Association Marketing Teaching Club, (In Hungarian: Magyar Marketing Szövetség Marketing Oktatók Klubja 18. Országos konferenciája), Miskolc, August 30-31.

13. Michalkó, G (2014), Városimázs és versenyképesség: a turizmusorientált településmarketing néhány aspektusa (City image and competitiveness: some aspects of tourism-oriented settlement marketing), in, Tózsa, I. (Ed.), Tourism and settlement marketing, BCE Department of Economic Geography and Future Research, Budapest. pp. 37-46.

14. Nagy, J. A. (2015), A városmarketing és a gazdasági szerkezetváltás összefüggései Manchesterben (The relationship between city marketing and economic change in Manchester), Tér és Társadalom (Space and Society), Vol. 29, No. 4, pp. 97-116.

15. Németh, K. (2017), Vidéki térségek innovációs kihívásai - Megújuló energia alternatívák (Innovation Challenges in Rural Areas - Renewable Energy Alternatives), Pannon Egyetemi Kiadó (University of Pannonia Publishing), Veszprém.

16. Palkó, K. (2011), Az identitás területi dimenziói a politika tükrében (The territorial dimensions of identity from a political viewpoint), PhD thesis, University of Pécs, Pécs.

17. Pataki, F. (1986), Identitás, személyiség, társadalom (Identity, personality, society), Akadémiai Kiadó, Budapest.

18. Péter, E. (2015), "Healthy healthcare system at Lake Balaton: Is healthy improvement or health improvement the solution for the Hungarian resort area?" Lambert Academic Publishing (LAP), Saarbrücken.

19. Péter, E., Németh, K., Kaszás, N. (2014), Egészségtudatosabb élelmiszer-fogyasztás vizsgálata Zala megyében - A vállalkozások szerepe az egészségmegőrzésben (Investigating Healthier Food Consumption in Zala County - The role of enterprises in 
health preservation), GAZDÁLKODÁs, Vol. 58, No. 6, pp. 552-563.

20. Piskóti, I. (2012), Régió- és településmarketing: marketingorientált fejlesztés, márkázás (Region and settlement marketing: marketing-oriented development, branding), Akadémiai Kiadó, Budapest.

21. Rainisto, S. K. (2003), Success factors of place marketing: A study of place marketing practices in Northern, Europe and the United States, Doctoral dissertation, Helsinki University of Technology, Helsinki,

22. Tóth-Kaszás, N. (2017), "A marketingkommunikációs mix" (The marketing communication mix), in Lőrincz, K., Sulyok, J. (Eds.), Turizmusmarketing (Tourism marketing), Akadémiai Kiadó, Budapest.

23. Zsarnoczky, M. (2016), "Innovation Challenges of the Silver Economy", Vadyba Journal of Management, Vol. 28, No. 1, pp. 105-109.

\section{About the authors}

Zoltán Birkner, $\mathrm{PhD}$ is an associate professor at University of Pannonia Nagykanizsa Campus, a research specialist in the field of innovation performance of companies and regions and the manager of a water technology research and development centre. The author can be contacted at birkner.zoltan@uni-pen.hu.

Tivadar Máhr is an active settlement development specialist, tourism and innovation expert, the deputy mayor of a highlighted touristic destination and PhD student in Management and Business Administration at the Doctoral School of University of Pannonia. The author can be contacted at mahrtivadar@gmail.com.

Nora Rodek, PhD is a senior lecturer at University of Pannonia Nagykanizsa Campus. She completed her PhD in Management and Business Administration at the Doctoral School of University of Pannonia. Her research topics are CSR (Corporate Social Responsibility), sustainable and responsible management, CSR strategy, social innovation. The author can be contacted at rodek.nora@gmail.com. 